\title{
What can we learn from experience? Impact of healthcare provider effects in the total or partial knee arthroplasty trial (TOPKAT)
}

\author{
Jonathan Cook', Graeme MacLennan², David Murray', Andrew Price', Ray Fitzpatrick', Andrew Carr, \\ Marion Campbell ${ }^{2}$, Helen Campbell', Nigel Arden' ${ }^{1}$, Cushla Cooper ${ }^{1}$, Loretta Davies ${ }^{1 *}$, TOPKAT Study Team', \\ David Beard ${ }^{1}$
}

From 3rd International Clinical Trials Methodology Conference

Glasgow, UK. 16-17 November 2015

Conducting multi-centre randomised controlled trials (RCTs) of surgical procedures raises specific issues in design, analysis and reporting. Interventions evaluated are usually complex and can be affected by factors such as surgical skill, decision making, preoperative and postoperative care. Variation between participating surgeons may have an important impact on the treatment effect.

The effect of healthcare provider (surgeon experience) was examined in the year 1 analysis of the TOPKAT study. This multi-centre, randomised controlled trial aims to assess the clinical and cost effectiveness of total or partial knee replacements for medial compartment osteoarthritis. The study has a combined expertise (7 sites)/equipoise (20 sites) design involving 64 surgeons in 27 secondary care orthopaedic units from across the UK. Both interventions evaluated are established and well-documented procedures. A minimal standard of experience was specified for entry into the study. Difference in prior surgeon experience with number of TKR procedures performed, median (IQR) 342 $(296,1000)$ compared to UKR $150(90,225)$, reflected that it is a more established procedure.

The influence of healthcare provider on treatment effect in the TOPKAT study will be reported. The importance of considering the impact of participating centres in the design, analysis and reporting of surgical RCTs will be discussed.

Authors' details

${ }^{1}$ University of Oxford, Oxford, UK. ${ }^{2}$ University of Aberdeen, Aberdeen, UK.

'University of Oxford, Oxford, UK

Full list of author information is available at the end of the article
Published: 16 November 2015

doi:10.1186/1745-6215-16-S2-P3

Cite this article as: Cook et al: What can we learn from experience? Impact of healthcare provider effects in the total or partial knee arthroplasty trial (TOPKAT). Trials 2015 16(Suppl 2):P3.
Submit your next manuscript to BioMed Central and take full advantage of:

- Convenient online submission

- Thorough peer review

- No space constraints or color figure charges

- Immediate publication on acceptance

- Inclusion in PubMed, CAS, Scopus and Google Scholar

- Research which is freely available for redistribution

Submit your manuscript at www.biomedcentral.com/submit
() Biomed Central 